\title{
Development of vegetable fibre-mortar composites of improved durability
}

\author{
Romildo D. Tolêdo Filho ${ }^{a}$, Khosrow Ghavami ${ }^{b, *}$, George L. England ${ }^{c}$, \\ Karen Scrivener ${ }^{\mathrm{d}}$ \\ ${ }^{a}$ Civil Engineering Department-COPPE, Federal University of Rio de Janeiro, P.O. Box 68506, CEP 21945-970, Brazil \\ ${ }^{\mathrm{b}}$ Civil Engineering Department, Pontificia Universidade Catolica, PUC-Rio, Rua Marquês de São Vicente, 225, Gávea, CEP 22453-900, \\ Rio de Janeiro, RJ Brazil \\ ${ }^{\mathrm{c}}$ Civl Engineering Department, Imperial College of Science Technology and Medicine, Imperial Collge Road, SW7 2BU, London, UK \\ d Laboratoire Central de Recherche-LAFARGE, 95 rue du Montmurier-B.P 15-38291, St Quentin Fallavier cedex, Lyon, France
}

Received 12 February 2001; accepted 30 April 2002

\begin{abstract}
The primary concern for vegetable fibre reinforced mortar composites (VFRMC) is the durability of the fibres in the alkaline environment of cement. The composites may undergo a reduction in strength and toughness as a result of weakening of the fibres by a combination of alkali attack and mineralisation through the migration of hydration products to lumens and spaces. This paper presents several approaches used to improve the durability performance of VFRMCs incorporating sisal and coconut fibres. These include carbonation of the matrix in a $\mathrm{CO}_{2}$-rich environment; the immersion of fibres in slurried silica fume prior to incorporation in the ordinary Portland cement (OPC) matrix; partial replacement of OPC matrix by undensified silica fume or blast-furnace slag and a combination of fibre immersion in slurried silica fume and cement replacement. The durability of the modified VFRMC was studied by determining the effects of ageing in water, exposure to cycles of wetting and drying and open air weathering on the microstructures and flexural behaviour of the composites. Immersion of natural fibres in a silica fume slurry before their addition to cement-based composites was found to be an effective means of reducing embrittlement of the composite in the environments studied. Early cure of composites in a CO2-rich environment and the partial replacement of OPC by undensified silica fume were also efficient approaches in obtaining a composite of improved durability. The use of slag as a partial cement replacement had no effect on reducing the embrittlement of the composite.
\end{abstract}

(C) 2002 Published by Elsevier Science Ltd.

Keywords: Sisal fibres; Coconut fibres; Cement; Mortar; Composite materials; Durability; Strength; Toughness; Weathering; Silica fume; Slag; Carbonation

\section{Introduction}

Cement pastes and mortars can be reinforced with vegetable fibres for manufacturing thin-walled building components with variable shapes. However, vegetable fibre cement composites undergo an ageing process in humid environments in which they may suffer a reduction in strength and toughness. This durability problem is associated with an increase in fibre fracture and de-

\footnotetext{
${ }^{*}$ Corresponding author. Tel.: +55-21-3114-1188; fax: $+55-21-3114-$ 1195 .

E-mail address: ghavami@civ.puc-rio.br (K. Ghavami).
}

crease in fibre pull-out due to a combination of weakening of the fibres by alkali attack, fibre mineralisation due to migration of hydration products to lumens and spaces and volume variation in these fibres due to their high water absorption [1-4]. To enhance the durability performance of vegetable fibre reinforced cement-based composites several approaches have been studied including fibre impregnation with blocking agents and water-repellent agents, either singly or in tandem, sealing of the matrix pore system, reduction of matrix alkalinity and combinations of fibre impregnation and matrix modification $[2,3]$.

Treatments of sisal fibres with blocking agents such as sodium silicate, sodium sulphite, magnesium sulphate, iron or copper compounds and barium and 
sulphite salts have been studied by Gram [2] but none of them have improved the durability of the fibre in a cement matrix. Fibre impregnation with water repellent agents was also studied but apart from formine and stearic acid, which led to a retardation of the embrittlement tendency of the composites, all other treatments (polyvinyl acetate, amide wax, silicon oil, tar, rubber latex, asphalt, etc.) failed to prevent the fibre from being mineralized [2]. Impregnation of sisal fibres with organic compounds derived from timber, such as tannins, colophony and vegetable oils, were studied by Canovas [3]. Their results indicated a slight slow down in the embrittlement process, but it was not avoided completely.

Sealing the matrix pores, admixing small beads of wax or zinc stearate powder in the fresh mortar, or impregnating the hardened product with sulphur showed promising results [2]. Pore sealing with colophony, tannin or montan wax reduced the water absorption and relative porosity of sisal fibre-mortar composites, slowing, but not halting, the embrittlement process [3].

Reduction of matrix alkalinity through the use of pozzolanic materials has been studied by several authors [2,4-6]. Materials studied have included high alumina cement and modified OPC-based materials containing silica fume, slag, fly ash or natural pozzolanas such as rice husk ash, pumice and diatomite. Replacing 45\% of the cement with silica fume eliminated the loss in toughness of the composite. A marked improvement was also observed when using high alumina cement and natural pozzolanas. With partial replacement of OPC by fly ash or slag, however, no significant improvement was obtained.

The approaches used in this research to improve the durability performance of VFRMCs incorporating sisal and coconut fibres included carbonation of the matrix in a $\mathrm{CO}_{2}$-rich environment, immersion of long fibres in slurried silica fume prior to their incorporation in an OPC mortar matrix and partial replacement of OPC by undensified silica fume and blast-furnace slag. A combination of fibre immersion in slurried silica fume and partial replacement of OPC by blast-furnace slag was also studied.

In this paper the results of tests on samples which have been aged under water or exposed to cycles of wetting and drying or to the natural weather are presented. The durability of the composites is discussed using the results of flexural tests carried out before and after 6 and 12 months ageing, and observations of fibres in a scanning electron microscope (SEM).

Reducing the embrittlement of vegetable fibre-cement composites is of great interest since an understanding of the means of doing so is needed to improve our ability to develop durable composites. The use of vegetable fibres in concrete provides an exciting challenge to the housing construction industry, particularly in non-industrialised countries, since they are a cheap and readily available form of reinforcement, require only a low degree of industrialisation for their processing and, in comparison with an equivalent weight of the most common synthetic reinforcing fibres, the energy required for their production is small and hence the cost of fabricating these composites is also low. In addition, the use of a random mixture of vegetable fibres in cement matrices leads to a technique that requires only a small number of trained personnel in the construction industry. Vegetable fibre cement composites thus pose the challenge and the solution for combining unconventional building materials with conventional construction methods.

\section{Experimental study}

\subsection{Materials}

The natural sisal and coconut fibres used in this investigation were of Brazilian production. The upper, lower, mean and coefficient of variation $(\mathrm{CV})$ of the physical and mechanical properties of these fibres based on a minimum of twenty tests are given in Table 1 $[4,7,8]$. The Thames Valley sand used in this investigation had a fineness modulus of 2.81 , specific gravity of

Table 1

Physical and mechanical properties of sisal and coconut fibres $[4,7,8]$

\begin{tabular}{|c|c|c|c|c|}
\hline \multirow[t]{2}{*}{ Property } & \multicolumn{2}{|l|}{ Sisal fibre } & \multicolumn{2}{|l|}{ Coconut fibre } \\
\hline & Lower-Upper & Mean-CV $(\%)$ & Lower-Upper & Mean-CV $(\%)$ \\
\hline Diameter (mm) & $0.08-0.30$ & $0.12-23.8$ & $0.11-0.53$ & $0.25-27.30$ \\
\hline Density $\left(\mathrm{g} / \mathrm{cm}^{3}\right)$ & $0.75-10.70$ & $0.90-8.90$ & $0.67-10.00$ & $0.80-7.60$ \\
\hline Natural moisture content $(\%)$ & $10.97-14.44$ & $13.30-8.80$ & $11.44-15.85$ & $13.5-10.00$ \\
\hline Water absorption after 5 min under water $(\%)$ & $67.00-92.00$ & $82.00-14.50$ & $22.00-38.00$ & $28.00-16.00$ \\
\hline Water absorption to saturation $(\%)$ & $190.00-250.00$ & $230.00-16.00$ & $85.00-135.00$ & $100.0-19.50$ \\
\hline Tensile strength $(\mathrm{MPa})$ & $227.80-1002.30$ & $577.50-42.66$ & $108.26-251.90$ & $174.00-24.20$ \\
\hline Modulus of elasticity (GPa) & $10.94-26.70$ & $19.00-29.50$ & $2.50-4.50$ & $3.50-27.00$ \\
\hline Strain at failure $(\%)$ & $2.08-4.18$ & $3.00-29.15$ & $13.70-41.00$ & $25.00-29.10$ \\
\hline
\end{tabular}


Table 2

Chemical and physical properties of the cementing materials

\begin{tabular}{|c|c|c|c|c|}
\hline Property & OPC & $\begin{array}{l}\text { Silica fume } \\
\text { grade } 940\end{array}$ & GGBS & $\begin{array}{l}\text { Slurry silica } \\
\text { fume }\end{array}$ \\
\hline \multicolumn{5}{|c|}{ Chemical properties } \\
\hline $\mathrm{SiO}_{2}(\%)$ & 20.7 & 91.7 & 34.4 & 92 \\
\hline $\mathrm{Fe}_{2} \mathrm{O}_{3}(\%)$ & 3.0 & 0.51 & 1.43 & 1.0 \\
\hline $\mathrm{Al}_{2} \mathrm{O}_{3}(\%)$ & 4.6 & 1.11 & 11.7 & 1.0 \\
\hline $\mathrm{CaO}(\%)$ & 64.7 & 0.23 & 41.2 & 0.3 \\
\hline $\mathrm{MgO}(\%)$ & 1.0 & 0.70 & 8.81 & 0.6 \\
\hline $\mathrm{SO}_{3}(\%)$ & 3.0 & 0.26 & - & 0.3 \\
\hline $\mathrm{Na}_{2} \mathrm{O}(\%)$ & 0.13 & 0.25 & 0.29 & 0.3 \\
\hline $\mathrm{K}_{2} \mathrm{O}(\%)$ & 0.65 & 1.11 & 0.31 & 0.8 \\
\hline $\mathrm{P}_{2} \mathrm{O}_{5}(\%)$ & - & 0.07 & - & - \\
\hline $\mathrm{T}_{\mathrm{i}} \mathrm{O}_{2}(\%)$ & - & 0.011 & 0.58 & - \\
\hline $\mathrm{MnO}(\%)$ & - & 0.033 & - & - \\
\hline $\mathrm{Mn}_{2} \mathrm{O}_{3}(\%)$ & - & - & 0.30 & - \\
\hline $\begin{array}{l}\text { Loss on } \\
\quad \text { ignition (\%) }\end{array}$ & 1.3 & 2.34 & - & - \\
\hline $\begin{array}{l}\text { Soluble } \\
\quad \text { residue }(\%)\end{array}$ & 0.38 & - & - & - \\
\hline $\mathrm{pH}$ & & 6.9 & - & $5.0-7.0$ \\
\hline \multicolumn{5}{|c|}{ Physical properties } \\
\hline $\begin{array}{l}\text { Fineness } \\
\qquad\left(\mathrm{m}^{2} / \mathrm{kg}\right)\end{array}$ & 353 & $15000-20000$ & 417 & - \\
\hline $\begin{array}{l}\text { Setting time- } \\
\quad \text { initial (min) }\end{array}$ & 134 & - & - & - \\
\hline \multicolumn{5}{|c|}{ Compressive strength (MPa) at: } \\
\hline 2 days & 26.63 & - & - & - \\
\hline 7 days & 47.2 & & - & - \\
\hline 14 days & 59.2 & & - & - \\
\hline $\begin{array}{l}\text { Bulk density } \\
\left(\mathrm{kN} / \mathrm{m}^{3}\right)\end{array}$ & - & 3.24 & - & $13.50-14.10$ \\
\hline $\begin{array}{l}\text { Dry solids } \\
\text { (by weight) }\end{array}$ & - & - & - & $50 \%( \pm 2 \%)$ \\
\hline
\end{tabular}

2.65 and total moisture content of $0.35 \%$, determined using the procedures specified in British Standard 812 [9]. Chemical and physical properties of the OPC, ground granulated blast-furnace slag (GGBS), undensified silica fume and slurry silica fume used are presented in Table 2. Tap water was used in all mixes.

A range of VFRMCs were prepared from these materials based on variations to the composition and curing of control composites as follows:

(i) control: OPC mortar matrix, reinforced with randomly distributed short $(25 \mathrm{~mm})$, untreated sisal or coconut fibres and aligned long $(375 \mathrm{~mm})$, untreated sisal fibres, cured 28 days;

(ii) carbonation of the matrix in a $\mathrm{CO}_{2}$ incubator: commencing one day after casting, specimens were conditioned in a $\mathrm{CO}_{2}$ incubator $\left(\mathrm{CO}_{2}=9.8 \%, T=26.7\right.$ ${ }^{\circ} \mathrm{C}$ and $\mathrm{RH}=64.3 \%$ ) for 109 days;

(iii) slurried silica fume immersed fibres: prior to their incorporation in the matrix, the aligned long sisal fibres were immersed in slurried silica fume for 10 min then air dried for $15 \mathrm{~min}$; (iv) undensified silica fume substitution in the matrix: $10 \%$ by weight of the OPC matrix replaced with undensified silica fume;

(v) blast furnace slag substitution in the matrix: $40 \%$ by weight of the OPC matrix replaced with blast furnace slag;

(vi) blast furnace slag substitution in the matrix and slurried silica fume immersed fibres: $40 \%$ by weight of the OPC matrix replaced with blast furnace slag, aligned long sisal fibres immersed in slurried silica fume.

Table 3 presents the summary of the mixes studied. In this Table, the following abbreviations are used to represent OPC mortar mix, fibre type, fibre arrangement, fibre volume fraction and treatment:

M1-mortar mix (1:1:0.4 cement:sand:water by weight);

M1ms - mortar mix M1 with $10 \%$ by weight of cement replaced by silica fume;

M1slag - mortar mix M1 with $40 \%$ by weight of cement replaced by slag;

$\mathrm{S}$ - sisal fibre;

C-coconut fibre;

Number after the fibre type-volume fraction of fibre $(\%)$;

S2S1-2\% of randomly distributed short sisal fibre (25 mm) plus $1 \%$ of aligned continuous sisal fibre (375 mm);

$\mathrm{C} 2 \mathrm{~S} 1-2 \%$ of randomly distributed short coconut fibre $(25 \mathrm{~mm})$ plus $1 \%$ of aligned continuous sisal fibre (375 mm);

i-aligned $375 \mathrm{~mm}$ long sisal fibres immersed in slurried silica fume prior to being added to the mix; $\mathrm{cab}$ - specimens conditioned in a $\mathrm{CO}_{2}$ incubator.

\subsection{Composite production}

Composites incorporating both random short fibre and aligned long fibre reinforcement were produced using the following procedure. The mortar matrix and short fibres were first mixed in a pan mixer. $40 \%$ of the total water required was added to the sand in the running mixer. In order to avoid clumping of fibres and to keep the mix wet enough, the fibres and a further $35 \%$ of the water were slowly added. After placing all the fibres and the cement, the remaining water was added to the running mixer which was allowed to continue for about 5 min to enhance fibre dispersion.

Test specimens, each measuring $400 \times 100 \times 15 \mathrm{~mm}$, were cast in wooden moulds made in such a way that seven specimens could be fabricated at the same time. To prepare an asymmetric reinforcing configuration, with the aligned fibres in the tension zone during flexure, first the homogeneously prepared mix was placed in a 
Table 3

Matrix and composite mix proportions

\begin{tabular}{|c|c|c|c|c|c|}
\hline Mix & $\begin{array}{l}\text { Mortar mix proportions } \\
\text { (by weight) }\end{array}$ & Applied treatments & Fibre type & $\begin{array}{l}\text { Volume fraction } \\
V_{\mathrm{f}}(\%)\end{array}$ & Orientation \\
\hline M1S2S1 & $1: 1: 0.4$ & Untreated & Sisal & $3=\mathrm{S} 2 \mathrm{~S} 1$ & Random + aligned \\
\hline $\mathrm{M} 1 \mathrm{C} 2 \mathrm{~S} 1$ & $1: 1: 0.4$ & Untreated & Coconut + Sisal & $3=\mathrm{C} 2 \mathrm{~S} 1$ & Random + aligned \\
\hline M1slagS2S1 & $(0.6 \mathrm{OPC}+0.4$ slag $): 1: 0.4$ & $\begin{array}{l}\text { Replacement }(40 \% \text { w/w) of OPC } \\
\text { with slag }\end{array}$ & Sisal & $3=\mathrm{S} 2 \mathrm{~S} 1$ & Random + aligned \\
\hline $\mathrm{M} 1 \mathrm{msS} 2 \mathrm{~S} 1$ & $(0.9 \mathrm{OPC}+0.1 \mathrm{MS}): 1: 0.46$ & $\begin{array}{l}\text { Replacement }(10 \% \mathrm{w} / \mathrm{w}) \text { of OPC } \\
\text { with silica fume }\end{array}$ & Sisal & $3=\mathrm{S} 2 \mathrm{~S} 1$ & Random + aligned \\
\hline $\mathrm{M} 1 \mathrm{~S} 2 \mathrm{~S} 1_{\mathrm{i}}$ & $1: 1: 0.4$ & $\begin{array}{l}\text { Aligned fibre immersed in slurry } \\
\text { silica fume }\end{array}$ & Sisal & $3=\mathrm{S} 2 \mathrm{~S} 1$ & Random + aligned \\
\hline M1slagS2S1 $1_{i}$ & $(0.6 \mathrm{OPC}+0.4$ slag $): 1: 0.4$ & $\begin{array}{l}\text { Replacement of OPC by slag } \\
(40 \% \mathrm{w} / \mathrm{w})+\text { immersion of } \\
\text { aligned fibre in slurry silica fume }\end{array}$ & Sisal & $3=\mathrm{S} 2 \mathrm{~S} 1$ & Random + aligned \\
\hline $\mathrm{M} 1 \mathrm{~S} 2 \mathrm{~S} 1_{\mathrm{cab}}$ & $1: 1: 0.4$ & Carbonation for 109 days & Sisal & $3=\mathrm{S} 2 \mathrm{~S} 1$ & Random + aligned \\
\hline $\mathrm{M} 1 \mathrm{C} 2 \mathrm{~S} 1_{\mathrm{cab}}$ & $1: 1: 0.4$ & Carbonation for 109 days & Coconut + Sisal & $3=\mathrm{C} 2 \mathrm{~S} 1$ & Random + aligned \\
\hline
\end{tabular}

layer about $3.5 \mathrm{~mm}$ thick in the wooden mould and then the long fibres were laid along the length of the specimen. Following compaction on a vibrating table the mould was filled completely with the randomly reinforced mortar mix and again vibrated as recommended by ACI 544.2R [10].

The specimens were covered in their moulds with a damp cloth and polythene sheet for $24 \mathrm{~h}$. After this time, they were demoulded and either cured for 28 days in a curing box at $18{ }^{\circ} \mathrm{C}$ and $97 \%$ relative humidity or placed directly in the $\mathrm{CO}_{2}$ incubator.

\subsection{Microstructural analysis}

Microstructural studies were carried out in a JOEL $35 \mathrm{CF}$ scanning electron microscope using secondary electron (se) imaging. The fibres examined were obtained from the failed bending test specimens. Fibres which had been pulled out from one fractured surface were cut out from the other, mounted on SEM stubs and gold coated prior to examination.

\subsection{Evaluation of composite durability}

The durability of the VFRMC was evaluated on the basis of the flexural properties of the specimens before and after exposure to various environments. Twentyone test specimens were cast for each mix. Three specimens were tested either after 28 days of curing or, in the case of the carbonated samples, after 109 days of carbonation, to provide a reference. The other 18 specimens were subjected to the three different ageing conditions which were: (a) immersion in water at a temperature of about $18{ }^{\circ} \mathrm{C}$, (b) controlled cycles of wetting and drying and (c) London open air weathering which started from the month of December 1994. In all conditions three specimens were tested after six months (the RH and outside temperature was registered to be between $30 \%$ and $45 \%$ and $15-20{ }^{\circ} \mathrm{C}$ respectively). The remainder tests were carried out after 10-12 months (the RH and outside temperature was registered to be between $55 \%$ and $74 \%$ and $5-15{ }^{\circ} \mathrm{C}$ respectively). Based on a series of controlled experiments the period of wetting and drying of VFRMC, was established to be seven days. During this period the specimens were kept under water at $18{ }^{\circ} \mathrm{C}$ for one day and dried for six days in the laboratory at 23 ${ }^{\circ} \mathrm{C}$ and $40 \%$ relative humidity [1].

The bending tests were carried out on a $2500 \mathrm{kN}$ Mayes testing machine using a four point configuration, $300 \mathrm{~mm}$ span and cross-head rate of $0.1 \mathrm{~mm} / \mathrm{min}$. The tests were ended when the displacement at mid-span reached 4-5 $\mathrm{mm}$. Immersed specimens were surface dried before testing. Tests on specimens subjected to controlled cyclic wetting and drying were carried out at the end of the drying period. Specimens subjected to outdoor weathering were tested in the ambient condition following surface wiping if wet. Deflections at mid-span were measured using three electrical transducers placed along the width of the specimen. Loads and corresponding deflections were continuously recorded using a 16 bit data acquisition system taking two readings/second. Fig. 1 shows the experimental set-up for the bending test.

From the load-deflection curves three parameters were calculated to evaluate the reinforcing effect of the fibre and consequently its durability or embrittlement with time for the cases studied:

(i) The post-crack flexural strength of the composite $\left(\sigma_{\mathrm{b}}\right)$ - determined from the maximum load carried out by the composite after the first crack event using the bending formula given by Eq. (1):

$$
\sigma_{\mathrm{b}}=6 M / b d^{2}
$$




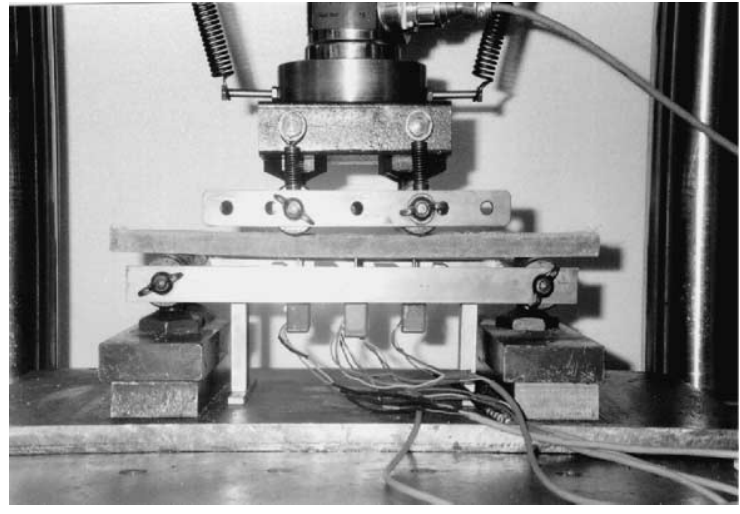

Fig. 1. Experimental set-up for the bending test.

where $M$ is the failure moment of the test specimen and $d$ and $b$ are the depth and width of the specimen, respectively.

(ii) The Japanese toughness index $\left(T_{\mathrm{JCI}}\right)[11]$-defined as the energy required to deflect the VFRMC beam to a midpoint deflection of $L / 150$ of its free span $(L)$ which in this study correspond to a deflection of $2 \mathrm{~mm}$.

(iii) The French and Belgian load ratios $P^{*}=P_{n} / P_{\mathrm{f}}$. The applied load at deflections of $0.5,1.0,1.4,2.0$ and $2.8 \mathrm{~mm}$ is defined as $P_{n}$ and that at the first visible crack is defined is $P_{\mathrm{f}}[12,13]$.

\section{Results and discussion}

It has been shown that VFRMCs undergo a reduction in strength and toughness as a result of weakening of the fibres by a combination of alkali attack and mineralisation through the migration of hydration products to lumens and spaces [1]. In the following the experimental results of several approaches used to improve the durability performance of VFRMCs incorporating sisal and coconut fibres are analysed. For the purpose of comparison with the present results data from reference [1] for aged untreated specimens reinforced with short and long fibres are also presented.

\subsection{Effect of carbonation of the matrix in a $\mathrm{CO}_{2}$ rich environment}

The $\mathrm{pH}$ value for the pore water in ordinary concrete or mortar normally exceeds 13 . This high alkalinity occurs due to the formation of calcium hydroxide, $\mathrm{Ca}(\mathrm{OH})_{2}$, during cement hydration. However, $\mathrm{Ca}(\mathrm{OH})_{2}$ may gradually disappear by combining with carbon dioxide $\left(\mathrm{CO}_{2}\right)$ to form calcium carbonate $\left(\mathrm{CaCO}_{3}\right)$ in the process known as carbonation. Once the concrete is car- bonated it becomes less alkaline and the $\mathrm{pH}$ value of the pore water can be reduced to a value less than 9 [14].

Results from Fattuhi [15] indicated that there is a relationship between the length of an initial water curing period and the rate of carbonation of concrete. In that author's work, concrete prisms of $50 \times 50 \times 285 \mathrm{~mm}$ were water-cured for 1, 3, 7, 21 and 28 days and then carbonated in a chamber filled continuously with $\mathrm{CO}_{2}$ gas. The results indicated that an increase in the initial water curing period led to a considerable decrease in the depth of carbonation.

Considering that a short initial curing period can increase the depth of carbonation, the VFRMCs to be carbonated were demoulded one day after casting and then immediately conditioned in a $\mathrm{CO}_{2}$ incubator in order to accelerate and achieve a high depth of carbonation. The chamber was maintained at conditions of $26.5{ }^{\circ} \mathrm{C}, 60 \%$ relative humidity and $9.8 \% \mathrm{CO}_{2}$ concentration using sodium dichromate. The relative humidity and temperature in the chamber rose for a brief period immediately after placing the specimens inside. The increase in relative humidity was the result of water liberation in the carbonation process of the damp one day old specimens. The carbonation was carried out over 109 days.

Typical examples of bending load-deflection curves obtained from untreated control specimens cured for 28 days, reference specimens carbonated for 109 days and specimens subjected to various ageing regimes after carbonation beside the result from the aged untreated composite M1S2S1 are presented in Fig. 2. A postcracking ductility behaviour is observed both for the control and reference specimens. The carbonation of the specimens reinforced with sisal fibres had a reduction of $9.2 \%, 8.8 \%$ and $6 \%$ for the first crack strength (FCS), post-crack flexural strength and toughness index $T_{\mathrm{JCI}}$ whereas the load ratios $P^{*}$ ranged from $2.1 \%$ to $10.2 \%$ (Table 4). The post-crack flexural strength and toughness index of the specimens reinforced with short coconut fibres had the same trend observed for M1S2S1 cab however the FCS had an increase of about $23 \%$ and the $P^{*}$ a decrease up to $40 \%$. The average recorded data based on three specimens with their $\mathrm{CV}$ is presented in Table 4.

Aged specimens of the mixes $\mathrm{M} 1 \mathrm{~S} 2 \mathrm{~S} 1_{\text {cab }}$ and M1C2S1 $1_{\text {cab }}$ retained about $70-93.5 \%$ of their $\sigma_{\mathrm{b}}$ and $T_{\mathrm{JCI}}$ values. The load-deflection curves of the specimens weathered outside indicate that the post-cracking ductility behaviour was retained. A second drop in load was observed for most of the carbonated specimens at a deflection of about $2.5 \mathrm{~mm}$ due to the onset of a second crack. The subsequent increase in load indicates that the fibres, at this stage of deflection, were still effective in redistributing the stresses into the matrix. 


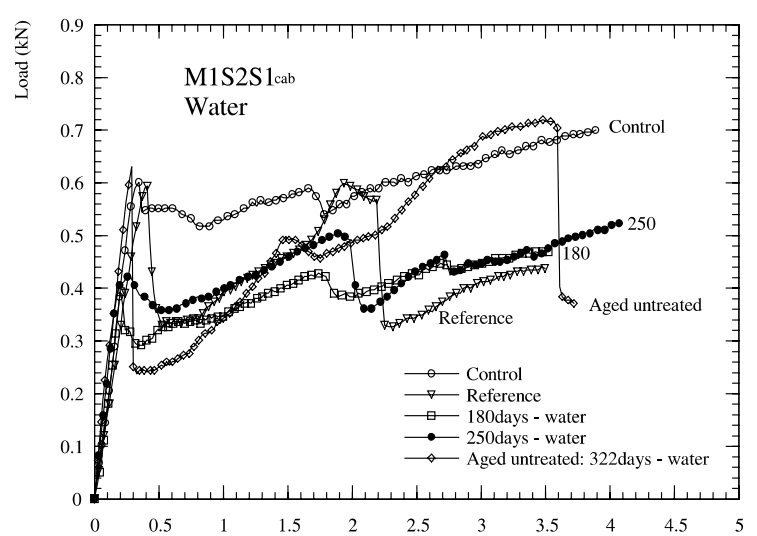

(a)

Deflection (mm)

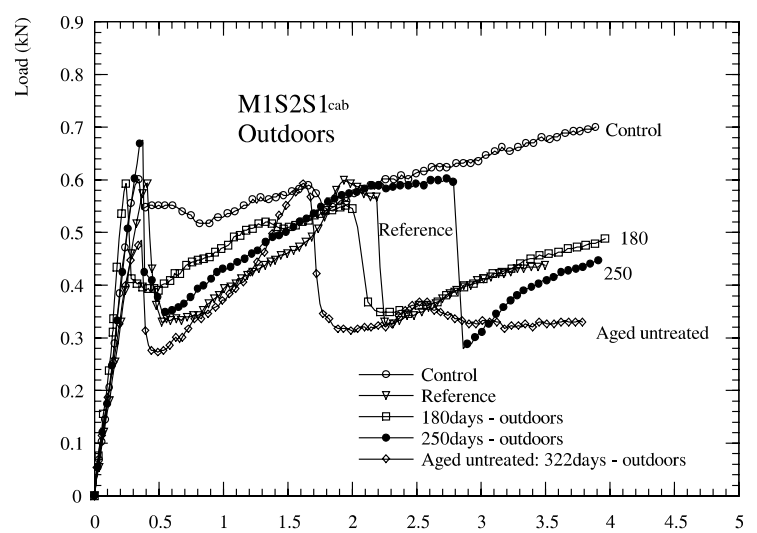

(b)

Deflection (mm)

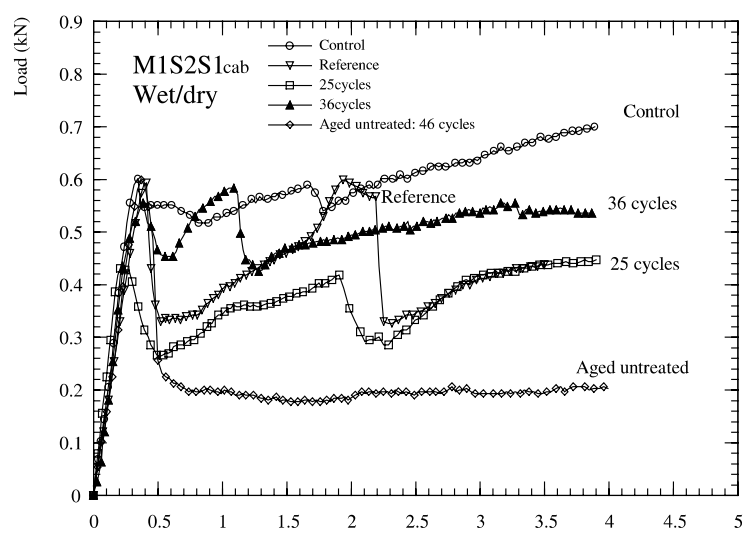

(c)

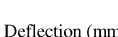

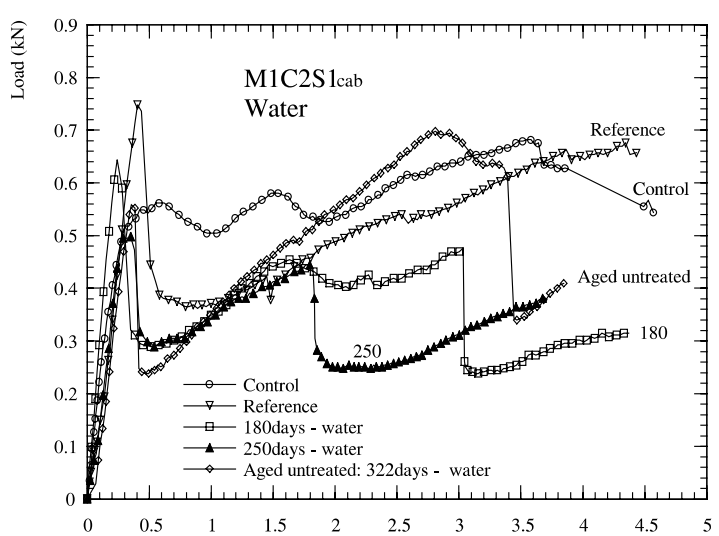

Deflection (mm)

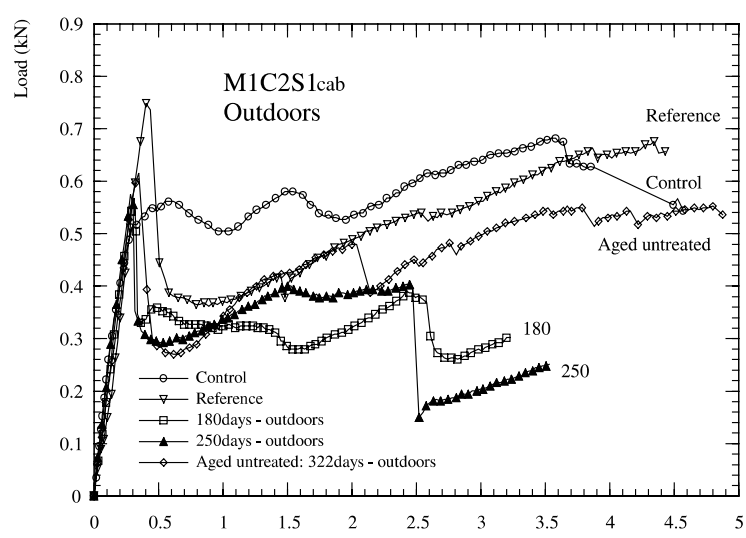

Deflection (mm)

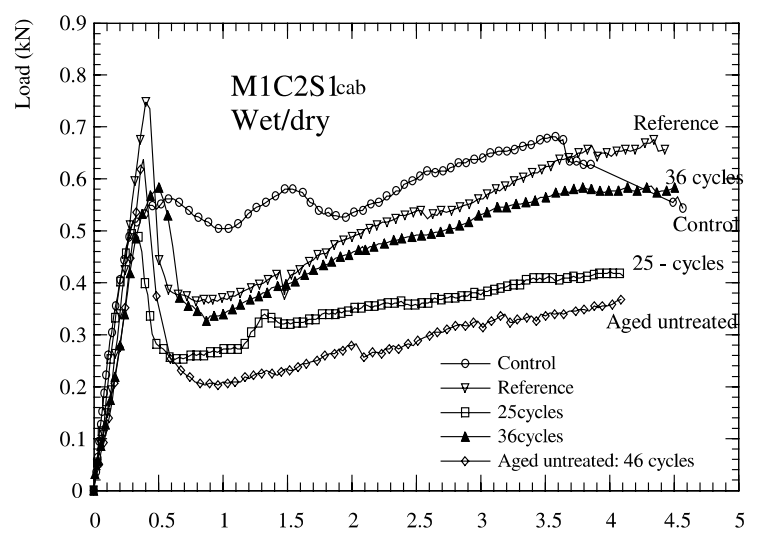

Deflection (mm)

Fig. 2. Typical load-deflection curves for the mixes $\mathrm{M} 1 \mathrm{~S} 2 \mathrm{~S} 1_{\mathrm{cab}}$ and $\mathrm{M} 1 \mathrm{C} 2 \mathrm{~S} 1_{\mathrm{cab}}$ aged in different conditions beside aged untreated $\mathrm{M} 1 \mathrm{~S} 2 \mathrm{~S} 1$ and M1C2S1: (a) Specimens stored in water after carbonation, (b) specimens aged outdoors after carbonation and (c) specimens submitted to cycles of wetting and drying after carbonation.

Although the bending tests on the carbonated samples were not realised up to 46 cycles after 322 days immersed in water or exposed to outdoor weather, the results indicated that carbonation of the specimens for 109 days is a promising alternative for increasing the durability of VFRMC. For example (see Table 4 and Fig. 2) the Japanese toughness, $T_{\mathrm{JCI}}$, of the
$\mathrm{M} 1 \mathrm{~S} 2 \mathrm{~S} 1_{\text {cab }}$ and $\mathrm{M} 1 \mathrm{C} 2 \mathrm{~S} 1_{\text {cab }}$ exposed to 25 and 36 cycles increased $64.4 \%, 107.5 \%$ and $28.7 \%, 42.2 \%$ respectively in relation to the M1S2S1 and M1C2S1 exposed to 46 cycles. The same trend can be observed for the $P^{*}$ parameters which have increased with the extending exposure from 25 to 36 cycles. Further research is needed to confirm the obtained data. This finding is very 
Table 4

FCS, $\sigma_{\mathrm{b}}, T_{\mathrm{JCI}}$, and $P^{*}$ for specimens after various periods of time conditioned in water, outdoors and alternately wet and dry

\begin{tabular}{|c|c|c|c|c|c|c|c|c|c|c|}
\hline Mix & $\begin{array}{l}\text { Ageing } \\
\text { condition }\end{array}$ & $\begin{array}{l}\text { Ageing } \\
\text { time (days) }\end{array}$ & $\begin{array}{l}\text { FCS(CV) } \\
(\mathrm{MPa})(\%)\end{array}$ & $\begin{array}{l}\sigma_{\mathrm{b}}(\mathrm{CV}) \\
(\mathrm{MPa})(\%)\end{array}$ & $\begin{array}{l}T_{\mathrm{JCI}}(\mathrm{CV}) \\
\mathrm{kN} \mathrm{mm}(\%)\end{array}$ & $P_{0.5}^{*}$ & $P_{1.0}^{*}$ & $P_{1.4}^{*}$ & $P_{2.0}^{*}$ & $P_{2.8}^{*}$ \\
\hline M1S2S1 & Control $^{\mathrm{a}}$ & 28 & $6.11(3)$ & $7.51(4)$ & $0.99(4)$ & 0.88 & 0.89 & 0.94 & 1.02 & 1.08 \\
\hline M1S2S1 & Water $^{\mathrm{a}}$ & 322 & $6.68(4)$ & $7.15(8)$ & $0.82(9)$ & 0.43 & 0.60 & 0.69 & 0.87 & 0.78 \\
\hline M1S2S1 & Outdoors $^{\mathrm{b}}$ & 322 & $5.20(16)$ & $5.60(3)$ & $0.86(17)$ & 0.59 & 0.70 & 0.95 & 0.79 & 0.67 \\
\hline M1S2S1 & Wet/dry ${ }^{\mathrm{c}}$ & 46 cycles & $6.03(12)$ & $3.06(14)$ & $0.49(10)$ & 0.46 & 0.39 & 0.39 & 0.46 & 0.47 \\
\hline $\mathrm{M} 1 \mathrm{~S} 2 \mathrm{~S} 1_{\mathrm{cab}}$ & Reference $^{\mathrm{a}}$ & 109 & $5.55(11)$ & $6.85(16)$ & $0.93(11)$ & 0.79 & 0.86 & 0.96 & 1.15 & 1.00 \\
\hline$"$ & Water $^{\mathrm{a}}$ & 180 & $4.22(14)$ & $5.03(11)$ & $0.74(10)$ & 0.81 & 0.88 & 1.00 & 1.17 & 0.90 \\
\hline$"$ & Water $^{\mathrm{a}}$ & 250 & $4.93(8)$ & $6.32(12)$ & $0.79(3)$ & 0.71 & 0.84 & 1.00 & 1.17 & 0.90 \\
\hline$"$ & Outdoors $^{\mathrm{b}}$ & 180 & $6.12(9)$ & $5.93(3)$ & $0.84(12)$ & 0.60 & 0.76 & 0.88 & 0.72 & 0.67 \\
\hline$"$ & Outdoors $^{\mathrm{b}}$ & 250 & $7.34(13)$ & $6.27(14)$ & $0.81(11)$ & 0.54 & 0.64 & 0.69 & 0.76 & 0.50 \\
\hline$"$ & Wet/dry ${ }^{\mathrm{c}}$ & 25 cycles & $5.05(8)$ & $5.03(10)$ & $0.66(10)$ & 0.62 & 0.68 & 0.73 & 0.76 & 0.88 \\
\hline$"$ & Wet/dry ${ }^{c}$ & 36 cycles & $6.34(14)$ & $6.35(10)$ & $0.87(8)$ & 0.86 & 0.91 & 0.85 & 0.83 & 0.95 \\
\hline $\mathrm{M} 1 \mathrm{C} 2 \mathrm{~S} 1$ & Control $^{\mathrm{a}}$ & 28 & $5.69(12)$ & $7.43(8)$ & $0.99(15)$ & 0.99 & 0.99 & 1.04 & 1.02 & 1.11 \\
\hline M1C2S1 & Water $^{\mathrm{a}}$ & 322 & $6.78(10)$ & $7.52(12)$ & $0.73(9)$ & 0.42 & 0.57 & 0.69 & 0.88 & 1.08 \\
\hline $\mathrm{M} 1 \mathrm{C} 2 \mathrm{~S} 1$ & Outdoors $^{\mathrm{b}}$ & 322 & $6.05(5)$ & $5.00(11)$ & $0.66(12)$ & 0.62 & 0.49 & 0.56 & 0.63 & 0.65 \\
\hline M1C2S1 & Wet/dry ${ }^{\mathrm{c}}$ & 46 cycles & $6.31(8)$ & $3.79(13)$ & $0.57(15)$ & 0.58 & 0.39 & 0.39 & 0.51 & 0.56 \\
\hline $\mathrm{M} 1 \mathrm{C} 2 \mathrm{~S} 1_{\mathrm{cab}}$ & Reference $^{\mathrm{a}}$ & 109 & $6.99(12)$ & $7.17(7)$ & $0.91(14)$ & 0.67 & 0.75 & 0.82 & 0.61 & 0.73 \\
\hline " & Water ${ }^{\mathrm{a}}$ & 180 & $7.65(13)$ & $5.57(15)$ & $0.75(12)$ & 0.45 & 0.54 & 0.66 & 0.63 & 0.69 \\
\hline$"$ & Water $^{\mathrm{a}}$ & 250 & $6.18(12)$ & $5.04(9)$ & $0.68(3)$ & 0.56 & 0.61 & 0.67 & 0.59 & 0.64 \\
\hline$"$ & Outdoors $^{\mathrm{b}}$ & 180 & $6.60(8)$ & $4.62(11)$ & $0.60(7)$ & 0.46 & 0.49 & 0.53 & 0.58 & 0.55 \\
\hline$"$ & Outdoors $^{\mathrm{b}}$ & 250 & $6.72(12)$ & $5.73(13)$ & $0.69(14)$ & 0.55 & 0.63 & 0.70 & 0.72 & 0.70 \\
\hline$"$ & Wet/dry ${ }^{\mathrm{c}}$ & 25 cycles & $5.72(11)$ & $4.88(12)$ & $0.61(15)$ & 0.57 & 0.55 & 0.67 & 0.70 & 0.75 \\
\hline$"$ & Wet/dry ${ }^{\mathrm{c}}$ & 36 cycles & $6.06(7)$ & $5.39(14)$ & $0.83(14)$ & 0.83 & 0.63 & 0.70 & 0.78 & \\
\hline $\mathrm{M} 1 \mathrm{~S} 2 \mathrm{~S} 1_{\mathrm{i}}$ & Reference $^{a}$ & 28 & $3.53(9)$ & $4.10(11)$ & $0.59(7)$ & 0.73 & 0.85 & 0.96 & 1.01 & 1.10 \\
\hline " & Water ${ }^{\mathrm{a}}$ & 180 & $5.97(10)$ & $6.16(13)$ & $0.92(3)$ & 0.54 & 0.78 & 0.78 & 0.80 & 0.87 \\
\hline$"$ & Water $^{\mathrm{a}}$ & 322 & $5.71(9)$ & $5.87(13)$ & $0.91(9)$ & 0.72 & 0.85 & 0.85 & 0.97 & 0.96 \\
\hline$"$ & Outdoors $^{\mathrm{b}}$ & 180 & $4.50(6)$ & $5.61(15)$ & $0.71(10)$ & 0.76 & 0.79 & 0.90 & 1.06 & 1.19 \\
\hline$"$ & Outdoors ${ }^{\mathrm{b}}$ & 322 & $5.49(11)$ & $5.81(4)$ & $0.93(3)$ & 0.78 & 0.93 & 1.03 & 1.03 & 0.87 \\
\hline$"$ & Wet/dry ${ }^{\mathrm{c}}$ & 25 cycles & $4.87(3)$ & $5.06(3)$ & $0.62(7)$ & 0.71 & 0.70 & 0.67 & 0.81 & 0.87 \\
\hline$"$ & Wet/dry ${ }^{\mathrm{c}}$ & 46 cycles & $5.21(13)$ & $5.52(15)$ & $0.84(10)$ & 1.01 & 0.88 & 0.87 & 0.87 & 0.91 \\
\hline $\mathrm{M} 1 \mathrm{msS} 2 \mathrm{~S} 1$ & Reference $^{\mathrm{a}}$ & 28 & $3.67(10)$ & $4.86(8)$ & $0.72(6)$ & 0.75 & 1.04 & 1.22 & 1.13 & 1.31 \\
\hline$"$ & Water $^{\mathrm{a}}$ & 180 & $5.17(2)$ & $5.51(13)$ & $0.72(13)$ & 0.51 & 0.67 & 0.80 & 0.87 & 0.76 \\
\hline$"$ & Water $^{\mathrm{a}}$ & 322 & $5.27(5)$ & $5.07(7)$ & $0.67(7)$ & 0.51 & 0.70 & 0.83 & 0.71 & 0.81 \\
\hline$"$ & Outdoors $^{\mathrm{b}}$ & 180 & $4.18(6)$ & 4.74(4) & $0.82(4)$ & 1.00 & 0.97 & 1.06 & 0.98 & 0.84 \\
\hline$"$ & Outdoors $^{\mathrm{b}}$ & 322 & $4.15(12)$ & $4.32(13)$ & $0.77(9)$ & 0.99 & 0.91 & 0.83 & 0.92 & 0.99 \\
\hline , & Wet/dry ${ }^{\mathrm{c}}$ & 25 cycles & $4.13(11)$ & $5.05(11)$ & $0.73(13)$ & 0.99 & 0.88 & 1.00 & 1.05 & 1.11 \\
\hline$"$ & Wet/dry ${ }^{\mathrm{c}}$ & 46 cycles & $4.46(8)$ & $4.44(11)$ & $0.83(9)$ & 0.99 & 0.97 & 0.80 & 0.85 & 0.97 \\
\hline M1slagS2S1 & Reference $^{\mathrm{a}}$ & 28 & $5.15(14)$ & $5.42(7)$ & $0.86(3)$ & 0.74 & 0.95 & 0.94 & 0.87 & 0.96 \\
\hline$"$ & Water $^{\mathrm{a}}$ & 180 & $5.98(8)$ & $5.30(14)$ & $0.71(13)$ & 0.60 & 0.61 & 0.55 & 0.79 & 0.74 \\
\hline$"$ & Water $^{\mathrm{a}}$ & 322 & $5.30(11)$ & $6.56(13)$ & $0.93(10)$ & 0.80 & 0.99 & 1.12 & 1.20 & 1.20 \\
\hline$"$ & Outdoors $^{\mathrm{b}}$ & 180 & $4.66(9)$ & $3.67(7)$ & $0.56(10)$ & 0.59 & 0.66 & 0.56 & 0.54 & 0.70 \\
\hline$"$ & Outdoors $^{\mathrm{b}}$ & 322 & $5.25(12)$ & $2.82(14)$ & $0.61(2)$ & 0.83 & 0.59 & 0.58 & 0.56 & 0.49 \\
\hline$"$ & Wet/dry ${ }^{\mathrm{c}}$ & 25 cycles & $5.73(5)$ & $4.14(7)$ & $0.80(8)$ & 0.84 & 0.67 & 0.67 & 0.65 & 0.69 \\
\hline$"$ & Wet/dry ${ }^{\mathrm{c}}$ & 46 cycles & $4.57(12)$ & $2.90(15)$ & $0.55(12)$ & 0.92 & 0.59 & 0.52 & 0.52 & 0.55 \\
\hline $\mathrm{M} 1$ slagS2S1 $1_{\mathrm{i}}$ & Reference $^{\mathrm{a}}$ & 28 & $4.28(4)$ & $4.94(7)$ & $0.65(5)$ & 0.69 & 0.81 & 0.80 & 0.89 & 1.01 \\
\hline " & Water $^{\mathrm{a}}$ & 180 & $4.83(12)$ & $6.23(13)$ & $0.79(11)$ & 0.61 & 0.83 & 1.03 & 1.25 & 1.21 \\
\hline$"$ & Water $^{\mathrm{a}}$ & 322 & $5.30(11)$ & $6.56(13)$ & $0.93(10)$ & 0.80 & 0.99 & 1.12 & 1.20 & 1.20 \\
\hline , & Outdoors $^{\mathrm{b}}$ & 180 & $4.37(3)$ & $6.10(10)$ & $0.72(12)$ & 0.77 & 0.87 & 0.95 & 1.03 & 1.24 \\
\hline$"$ & Outdoors $^{\mathrm{b}}$ & 322 & $4.42(13)$ & $4.95(12)$ & $0.64(7)$ & 0.67 & 0.74 & 0.83 & 1.01 & 1.12 \\
\hline$"$ & Wet/dry ${ }^{\mathrm{c}}$ & 25 cycles & $4.09(9)$ & $5.13(14)$ & $0.60(10)$ & 0.62 & 0.74 & 0.79 & 1.01 & 1.12 \\
\hline$"$ & Wet/dry ${ }^{\mathrm{c}}$ & 46 cycles & $3.95(4)$ & $5.12(11)$ & $0.74(11)$ & 1.13 & 1.26 & 1.30 & 1.23 & 1.39 \\
\hline
\end{tabular}

Mean values determined from three specimens.

${ }^{\mathrm{a}}$ Moisture content of the specimen at the time of test: (a) saturated.

${ }^{\mathrm{b}}$ Moisture content of the specimen at the time of test: (b) intermediate.

${ }^{\mathrm{c}}$ Moisture content of the specimen at the time of test: (c) dry.

important at the present time when the cement industry has grown drastically and is contributing to the pollu- tion of the world through the emission of the $\mathrm{CO}_{2}$ which can be transferred to the VFRMC production factory. 


\subsection{Effect of treatment of aligned long sisal fibre with slurried silica fume}

An alternative approach used by Bentur and Diamond [16] to improve the durability of glass fibre strand reinforced concrete was considered in this study. They treated the glass strands by immersing them in a silica fume slurry prior to their being incorporated in a Portland cement matrix. Using this treatment, they meant to resolve the two mechanisms which cause fibre degradation: chemical attack on the glass fibre by the highly alkaline cementitious matrix and growth of dense hydration products, mainly calcium hydroxide, around the filaments in the strands. During the immersion period the spaces between the glass filaments are filled with microsilica particles. By this procedure, the microsilica particles are placed exactly at the location where their ability to eliminate efficiently the growth of calcium hydroxide is most needed.

As the two main mechanisms that produce fibre degradation in VFRMC are alkaline attack and fibre mineralisation caused by the migration of hydration products into the fibre lumen and walls, long sisal fibres were immersed in silica fume slurry prior to being incorporated in the OPC matrix to create a zone of low $\mathrm{pH}$ around the fibres in order to avoid or reduce alkaline attack and the transport of calcium products to the vegetable fibres.

Typical examples of load-deflection curves for the unaged and aged VFRMCs incorporating silica treated fibres are presented in Fig. 3 and the derived parameters, $\sigma_{\mathrm{b}}, T_{\mathrm{JCI}}$ and $P^{*}$, in Table 4 . A comparison of the values of FCS, flexural strength and toughness of the untreated and treated sisal fibre-mortar at 28 days shows that the treatment resulted in reductions of $30-40 \%$. Decreases in these properties occurred because the immersion of fibres in slurry silica fume led to reduced bonding between the fibres and matrix at this age. Visual observations of the fracture surface indicated that the slurry silica fume around the fibres was still slightly soft at this age. After 180 days of ageing the treated specimens presented higher FCS, flexural strength and toughness than those at the age of 28 days. For example, the specimens cured in water presented an increase of, respectively, $50 \%$ and $38 \%$ in the values of $\sigma_{\mathrm{b}}$ and $T_{\mathrm{JCI}}$ when compared with those measured at 28 days (see Table 4). The load ratio indices indicate a post-cracking ductility behaviour which is confirmed in Fig. 5. Visual observations of the fracture surface indicated that the silica fume around the fibres was significantly harder than at 28 days.

Flexural strength and toughness were further improved after 322 days of ageing. For example, $T_{\mathrm{JCI}}$ values for the aged treated specimens ranged from $85 \%$ to $94 \%$ of the control specimen. A similar trend was observed for the flexural strength. Visual observations of

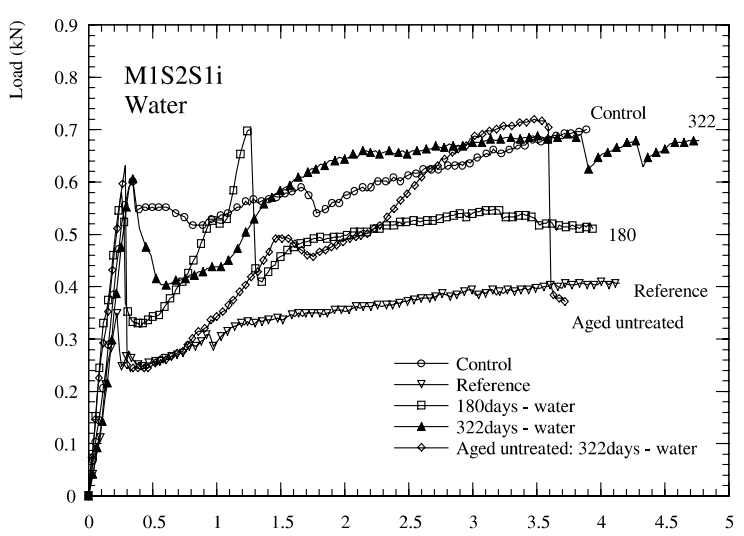

(a)

Deflection (mm)

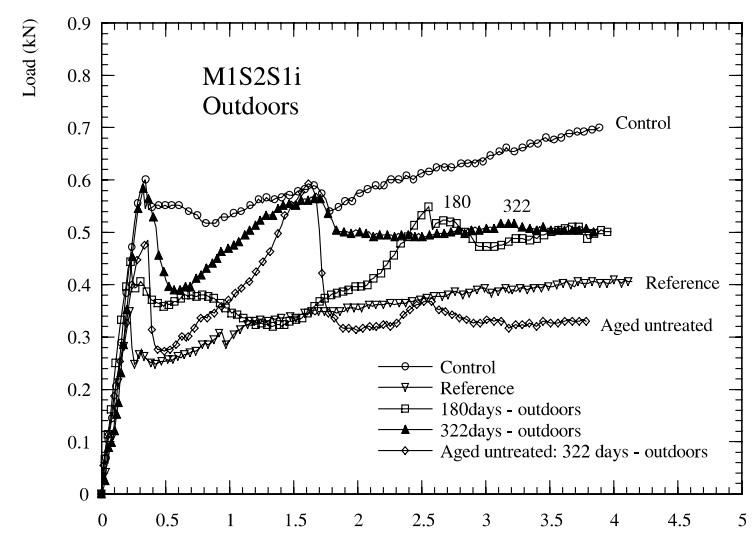

(b)

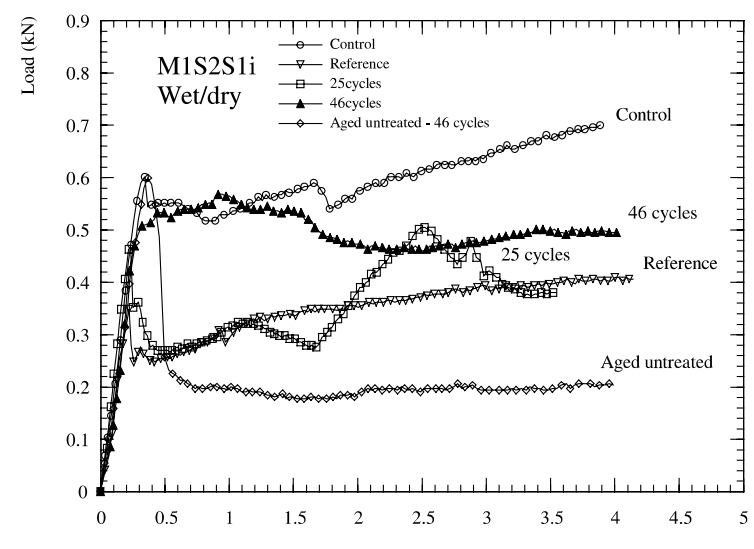

(c)

Deflection (mm)

Fig. 3. Typical load-deflection curves for the mix M1S2S1i aged in different conditions beside aged untreated M1S2S1 and M1C2S1: (a) specimens stored in water, (b) specimens aged outdoors and (c) specimens submitted to 25 and 46 cycles of wetting and drying.

fibres extending from the failure surfaces of composites tested after 46 cycles of wetting and drying indicated that the pull out length of the fibres could amount to $50-70 \mathrm{~mm}$ and that they could be regarded as being as flexible and strong as fibres in control specimens. Scanning electron micrograph of long sisal fibres showing the changes in the fibre surface with ageing are 

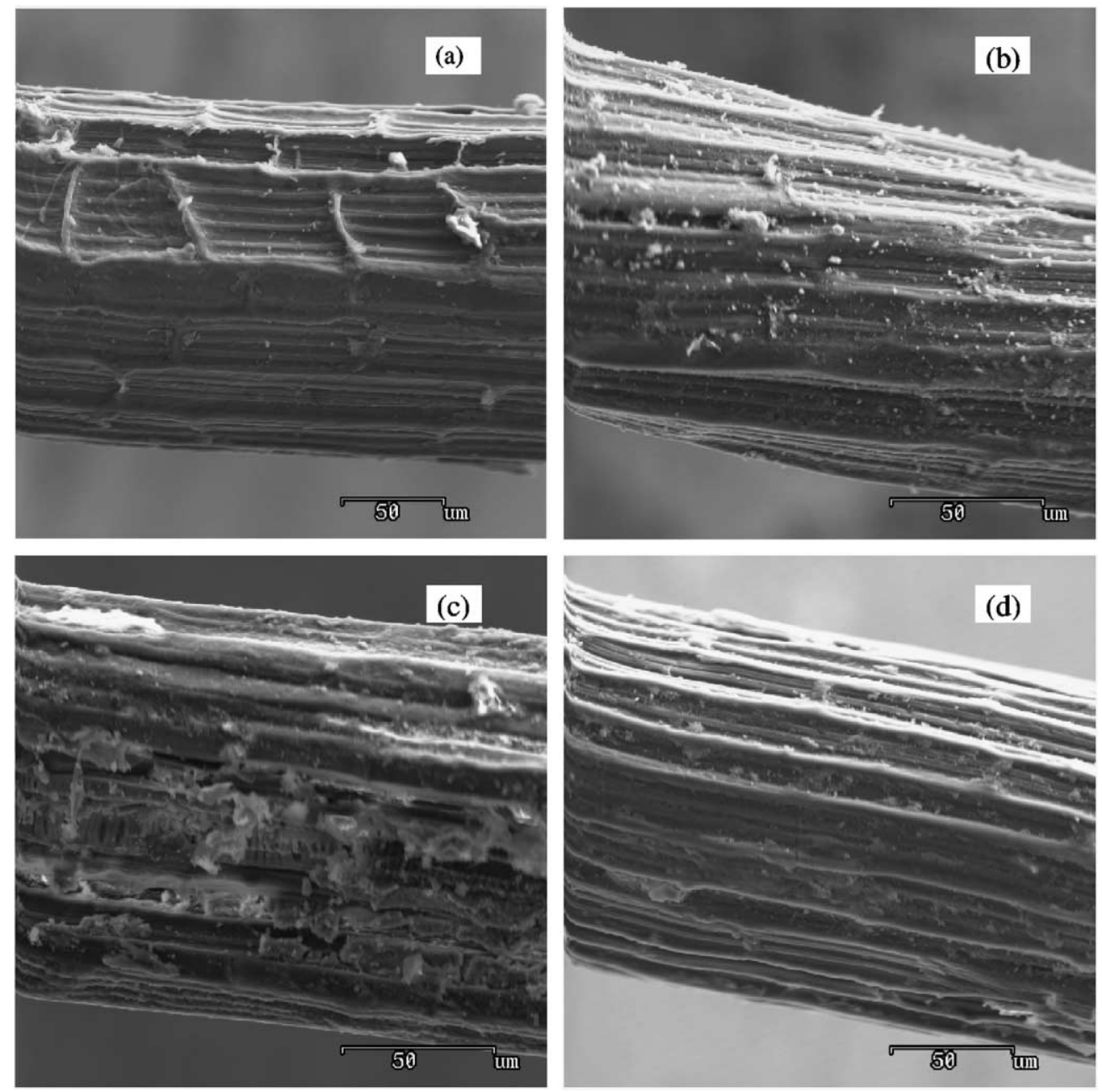

Fig. 4. Scanning electron micrographs of sisal fibre surfaces before and after ageing: (a) Before ageing, (b) fibre extracted from a specimen aged for 322 days in tap water, (c) fibre extracted from a specimen aged for 322 days outdoors and (d) fibre extracted from a specimen submitted to 46 cycles of wetting and drying.

presented in Fig. 4. From these micrographs it can be seen that the surface of the immersed sisal fibre does not present signs of significant damage up to 322 days of ageing.

The results presented show that the immersion of sisal fibres in slurried silica fume prior to their incoporation in a mortar matrix represents an effective method to improve the strength and toughness of the composites with time. The presence of silica fume at the fibre-matrix interface appears to create a zone of low alkalinity around the fibre which can delay or prevent degradation of the fibre by alkaline attack or mineralisation through the migration of calcium products.

\subsection{Effect of silica fume and slag substitution in the matrix}

The use of pozzolanic fillers, such as silica fume and slag, can reduce the alkalinity of the matrix as well as the content of calcium hydroxide, and thus slow down the processes which lead to degradation in the properties of VFRMC. The replacement of $10 \%$ and $40 \%$ by weight of the OPC with, respectively, undensified silica fume and blast-furnace slag were treatments used in this investigation to reduce the alkalinity of the matrix.

Typical examples of bending load-deflection curves of aged specimens, and those of the control and reference specimens are presented in Fig. 5. The parameters $\sigma_{\mathrm{b}}, T_{\mathrm{JCI}}$ and $P^{*}$ are recorded in Table 4 . For the mix with undensified silica fume, the results show that the specimens stored for 322 days in water, aged outdoors or submitted to 46 cycles of wetting and drying presented nearly the same properties as those observed for the treated specimen tested at 28 days. Again a post-cracking ductility behaviour was observed both at 28 days and after ageing. The addition of silica fume reduced by about $40 \%$ the value of the FCS of the reference specimen as compared with the control specimen. However the ageing of the specimens in time led to an increase of $12-43 \%$ in the FCS values in relation to reference specimen. 

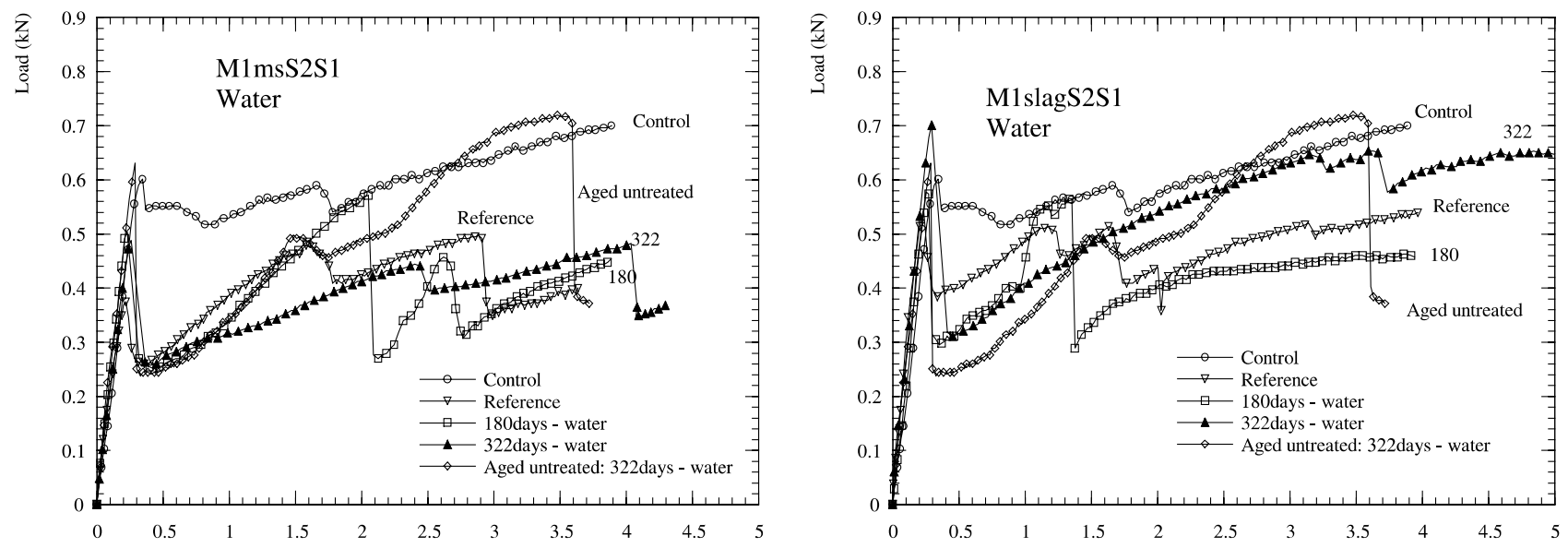

(a)

Deflection (mm)
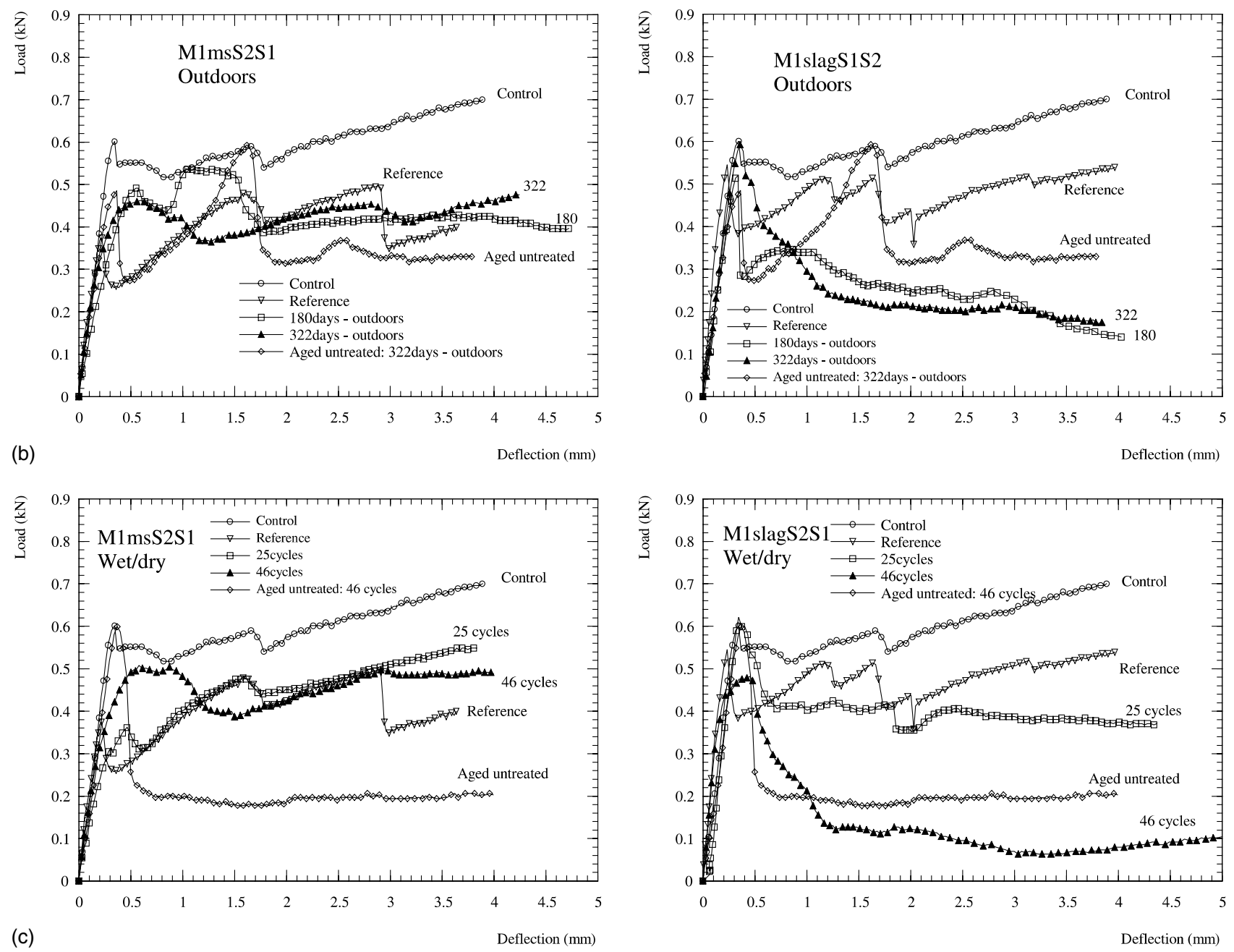

Fig. 5. Typical load-deflection curves for the mixes M1msS2S1 and M1slagS2S1 aged in different conditions: (a) Specimens stored in water, (b) specimens aged outdoors and (c) specimens submitted to 25 and 46 cycles of wetting and drying.

Partial replacement of OPC by blast-furnace slag did not lead to reduced embrittlement with ageing under conditions of cyclic wetting and drying. This is most probably due to the limited effect of the replacement on alkalinity, the $\mathrm{pH}$ of the pore water not being sufficiently reduced to prevent fibre degradation. Replacement of $70 \%$ of OPC by slag was used by Gram [2] to reduce the alkalinity of the matrix but the results of that work in- 
dicated that the $\mathrm{pH}$ of the pore water was reduced only from 13.2 to 13.0 and that no improvement in the durability of sisal-mortar composites was achieved.

The specimens aged in water presented a better behaviour. For example, the parameters $\sigma_{\mathrm{b}}$ and $T_{\mathrm{JCI}}$ for specimens stored in water for 322 days are, respectively, about $20 \%$ and $8 \%$ higher than the values observed before ageing. In contrast to the specimens exposed outdoors, specimens stored in water also present a postcracking ductility behaviour after ageing, with the load at a deflection of $2.8 \mathrm{~mm}$ reaching a value $20 \%$ higher than the first crack load.

The results obtained indicate that the treatment of the matrix with undensified silica fume was an effective means of slowing down the strength loss and embrittlement of the VFRMC. The specimens incorporating slag were quite sensitive to the cycles of wet and dry and presented a strong deterioration with time.

\subsection{Effect of slag substitution in the matrix with silica fume slurry immersed fibres}

The effect of the immersion of the aligned long sisal fibres in a silica fume slurry prior to their addition to a matrix in which $40 \%$ by weight of the OPC was replaced with blast-furnace slag was also studied. Typical loaddeflection curves at 28 days and after ageing are presented in Fig. 6. The derived parameters, $\sigma_{\mathrm{b}}, T_{\mathrm{JCI}}$, and $P^{*}$, are presented in Table 4 .

As already observed for the mix M1S2S1i, the immersion of fibres in slurried silica fume led to a reduction, at the age of 28 days, in the values of FCS, post-crack flexural strength and toughness compared to those of specimens reinforced with untreated sisal fibre (mix M1S2S1). However, as was the case with mix M1S2S1i, they underwent a significant increase with time. For example, the specimens stored in water for 180 days presented values of $\sigma_{\mathrm{b}}$ and $T_{\mathrm{JCI}}$, respectively, $27.5 \%$ and $21.5 \%$ higher than the values observed at the age of 28 days. After 322 days in water, the toughness of the mix Mslag1S2S1i reached $91 \%$ of the toughness of the control specimens.

The specimens weathered outdoors for 322 days or submitted to cycles of wetting and drying presented nearly the same property values as those observed for the reference specimens. All load-deflection curves indicated a post-cracking ductility behaviour after 322 days of ageing. These results show that the immersion of fibres in slurried silica fume led to a retention of composite flexural toughness and strength with age. As the results of the tests carried out with slag-cement as a binder indicated that this treatment did not reduce the tendency of embrittlement with ageing of the mix (Mslag1S2S1, Fig. 5), the enhancement in the durability observed for the mix Mslag1S2S1i can be attributed to the treatment of the fibres with silica fume slurry. These

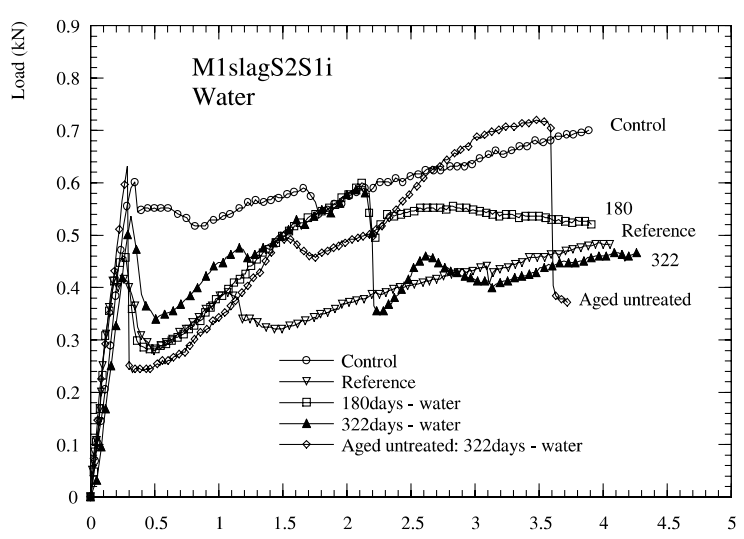

(a)

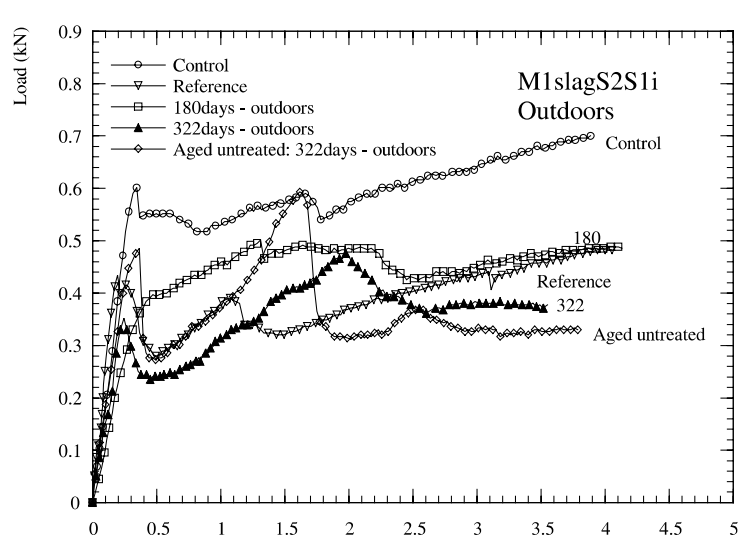

(b)

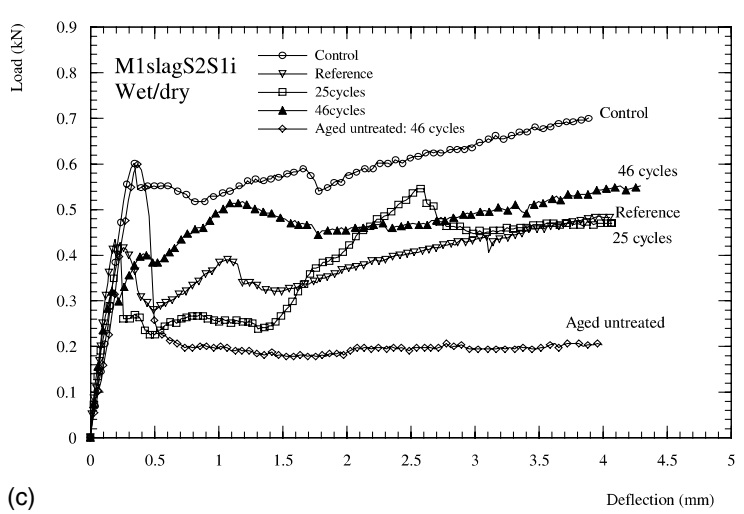

Fig. 6. Typical load-deflection curves for mix M1slagS2S1i aged in different conditions: (a) Specimens stored in water, (b) specimens aged outdoors and (c) specimens submitted to 25 and 46 cycles of wetting and drying.

results confirm those observed for the mix M1S2S1i, demonstrating the effectiveness of the treatment using slurried silica fume in preventing vegetable fibre embrittlement.

\section{Conclusions}

Based on the results presented in this paper it can be concluded that long-term embrittlement of VFRMC 
incorporating sisal fibre can be markedly reduced by immersion of the fibre in a silica fume slurry before adding it to the mix. Long-term properties of the treated specimens were found to be very close to those of the 28 days untreated control specimens. Early cure of VFRMC in a $\mathrm{CO}_{2}$-rich environment is a promising alternative for increasing the durability of the material with ageing. Further research is needed to confirm the obtained data. The durability of the VFRMCs studied was also improved by reducing the alkalinity of the mortar pore water through addition of undensified silica fume. The replacement of $40 \%$ by mass of the OPC matrix with slag did not reduce the embrittlement of the composite. In this case the toughness of the composite was reduced by wet/dry cycling both outdoors and in the laboratory.

\section{Acknowledgements}

The authors would like to thank the financial support given by Brazilian agencies CAPES, FAPERJ, CNPq and the British Council.

\section{References}

[1] Tolêdo Filho RD, Scrivener K, England GL, Ghavami K. Durability of alkali sensitive sisal and coconut fibres in cement based composites. Cement Concrete Comp 2000;6(22):127-43.

[2] Gram HE. Durability of natural fibres in concrete, Swedish Cement and Concrete Research Institute, Research Fo. 1:83, Stockholm, 1983. p. 255.

[3] Canovas SK. New economical solutions for improvement of durability of portland cement mortars reinforced with sisal fibres. Mater Struct 1992;25:417-22.
[4] Tolêdo Filho RD. Natural fibre reinforced mortar composites: experimental characterisation, $\mathrm{PhD}$ thesis, DEC-PUC-Rio, Brazil, 1997. p. 472.

[5] John VM, Agopyan V, Derolle A. Durability of blast furnaceslag-based cement mortar reinforced with coir fibres. In: Second International Symposium on vegetable plants and their fibres as Building Materials, RILEM Proc 7. London: Chapman and Hall; 1990. p. 87-97.

[6] Berhane Z. Performance of natural fibre reinforced mortar roofing tiles. Mater Struct 1999;27:347-52.

[7] Tolêdo Filho RD, Joseph K, Ghavami K, England GL. The use of sisal fibre as reinforcement in cement based composites. Braz $\mathrm{J}$ Agri Environ Eng 1999;3(2):245-56.

[8] Ghavami K, Tolêdo Filho RD, Barbosa NP. Behaviour of composite soil reinforced with natural fibres. Cement Concrete Comp 1999;21:39-48.

[9] BS 812: Part 103. Methods for determination of particle size distribution, British Standard Association, London, 1985.

[10] ACI 544.2R, Measurement of properties of fiber reinforced concrete, American Concrete Institute, Detroit, Michigan, USA, 1989.

[11] JCI SF4, Method of test for flexural strength and flexural toughness of fibre reinforced concrete, JCI Standards for Test Methods of Fibre Reinforced Concrete, Japan Concrete Institute, Japan, 1983. p. 45-51.

[12] AFNOR Normalisation Française P18-409, "Béton avec Fibres Métalliques-Essai de Flexion”, P18-409, L'association Française de Normalisation (AFNOR), France, 1993. p. 8.

[13] Norme Belge NBN B 15 238, Essais des bétons reforcé de fibresEssai de flexion sur éprouvettes prismatiques, Institut Belge de Normalisation (IBN), Brussels, 1992. p. 9.

[14] Hobbs DW. Carbonation of concrete containing PFA. Mag Concrete Res 1988;40(143):69-78.

[15] Fattuhi NI. Carbonation of concrete as affected by mix constituents and initial water curing period. Mater Construc 1986; 19(110):131-5.

[16] Bentur A, Diamond S. Direct incorporation of silica fume into strands as a means for developing GFRC composite of improved durability. Int J Cement Comp Lightweight Concrete 1987;(9): 127-36. 